\title{
Policy brief: Round goby - a threat or a new resource?
}

\author{
Behrens, Jane; van Deurs, Mikael; Puntila, Riikka; Florin, Ann-Britt
}

Link to article, DOI:

$10.6027 / \mathrm{NO} 2019-037$

Publication date:

2019

Document Version

Publisher's PDF, also known as Version of record

Link back to DTU Orbit

Citation (APA):

Behrens, J., van Deurs, M., Puntila, R., \& Florin, A-B. (2019). Policy brief: Round goby - a threat or a new resource? Nordic Council of Ministers. Nord No. 2019:037 https://doi.org/10.6027/NO2019-037

\section{General rights}

Copyright and moral rights for the publications made accessible in the public portal are retained by the authors and/or other copyright owners and it is a condition of accessing publications that users recognise and abide by the legal requirements associated with these rights.

- Users may download and print one copy of any publication from the public portal for the purpose of private study or research.

- You may not further distribute the material or use it for any profit-making activity or commercial gain

- You may freely distribute the URL identifying the publication in the public portal

If you believe that this document breaches copyright please contact us providing details, and we will remove access to the work immediately and investigate your claim 


\section{III) Nordic Council of Ministers}




Policy brief: Round goby - a threat or a new resource?

Jane W. Behrens, Mikael van Deurs, Riikka Puntila-Dodd, Ann-Britt Florin

Nord 2019:037

ISBN 978-92-893-6272-6 (PDF)

ISBN 978-92-893-6273-3 (EPUB)

http://dx.doi.org/10.6027/NO2019-037

(c) Nordic Council of Ministers 2019

Layout: Mette Agger Tang

Cover Photo: Shutterstock

\section{Nordic co-operation}

Nordic co-operation is one of the world's most extensive forms of regional collaboration, involving Denmark, Finland, Iceland, Norway, Sweden, the Faroe Islands, Greenland, and Åland.

Nordic co-operation has firm traditions in politics, the economy, and culture. It plays an important role in European and international collaboration, and aims at creating a strong Nordic community in a strong Europe.

Nordic co-operation seeks to safeguard Nordic and regional interests and principles in the global community. Shared Nordic values help the region solidify its position as one of the world's most innovative and competitive.

\section{Nordic Council of Ministers}

Nordens Hus

Ved Stranden 18

DK-1061 Copenhagen

www.norden.org

Download and order Nordic publications from www.norden.org/nordpub 


\section{Policy Brief}

\section{Round goby \\ - a threat or \\ a new resource?}

\section{Content}

05 Round goby - a threat or a new resource?

06 The pan-Baltic invasion history of round goby and examples of negative impacts

09 Round goby in relation to Good Environmental Status and Marine Protected Areas

11 Round goby as an emerging prey item and potential new resource

13 Conclusions and recommendations 


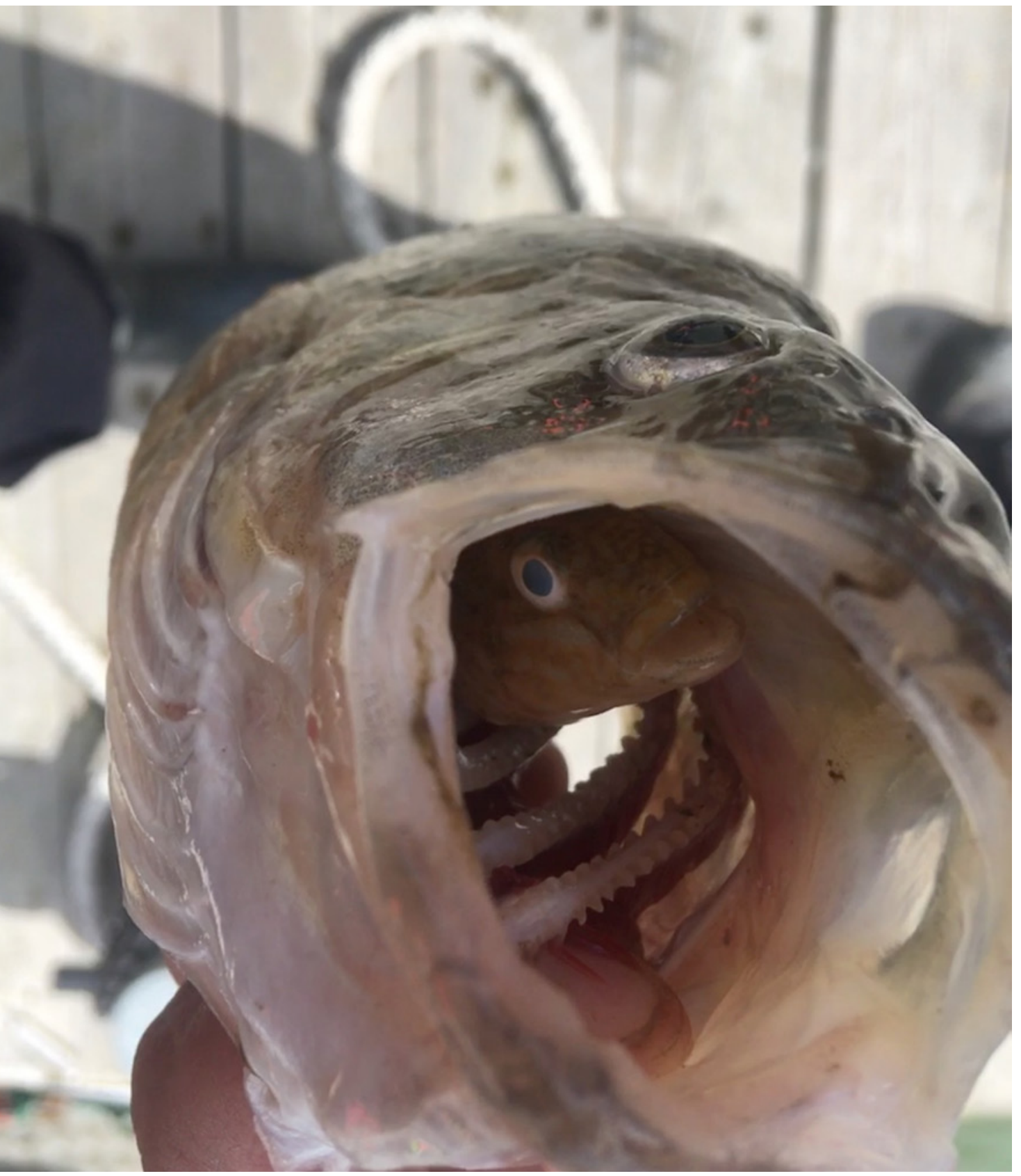

European perch eating round goby. Photo: Riikka Puntila-Dodd 个 


\section{Round goby}

- a threat or a new resource?

Since it was first observed in 1990 in the Polish Gulf of Gdansk, the round goby has established dense populations in many coastal areas throughout the Baltic region. Round goby is considered an invasive species with several documents of negative effects occurring in the wake of its invasion, e.g. reduction or even elimination of benthic prey species such as mussels and shrimps, and reducing abundance of commercially important fish species through competition for food and territory. Yet, in recent years, emerging evidence points to that this new fish may also constitute a supplementary prey for piscivorous predators.

To fully understand the impact and role of round goby in invaded ecosystems, not only the hazardous effects of this invasive species should be documented, but also potential benefits arising from its presence. The latter includes both the potential for round goby as a new resource for the fishing industry, a matter currently addressed by several countries around the Baltic, and also round goby as prey for piscivorous fish, marine birds and mammals.

This policy brief summarizes the status for the invasion of round goby in the Baltic region, and elucidate available knowledge on the potential for round goby as an emerging prey, including suggestions for future research and management efforts. 


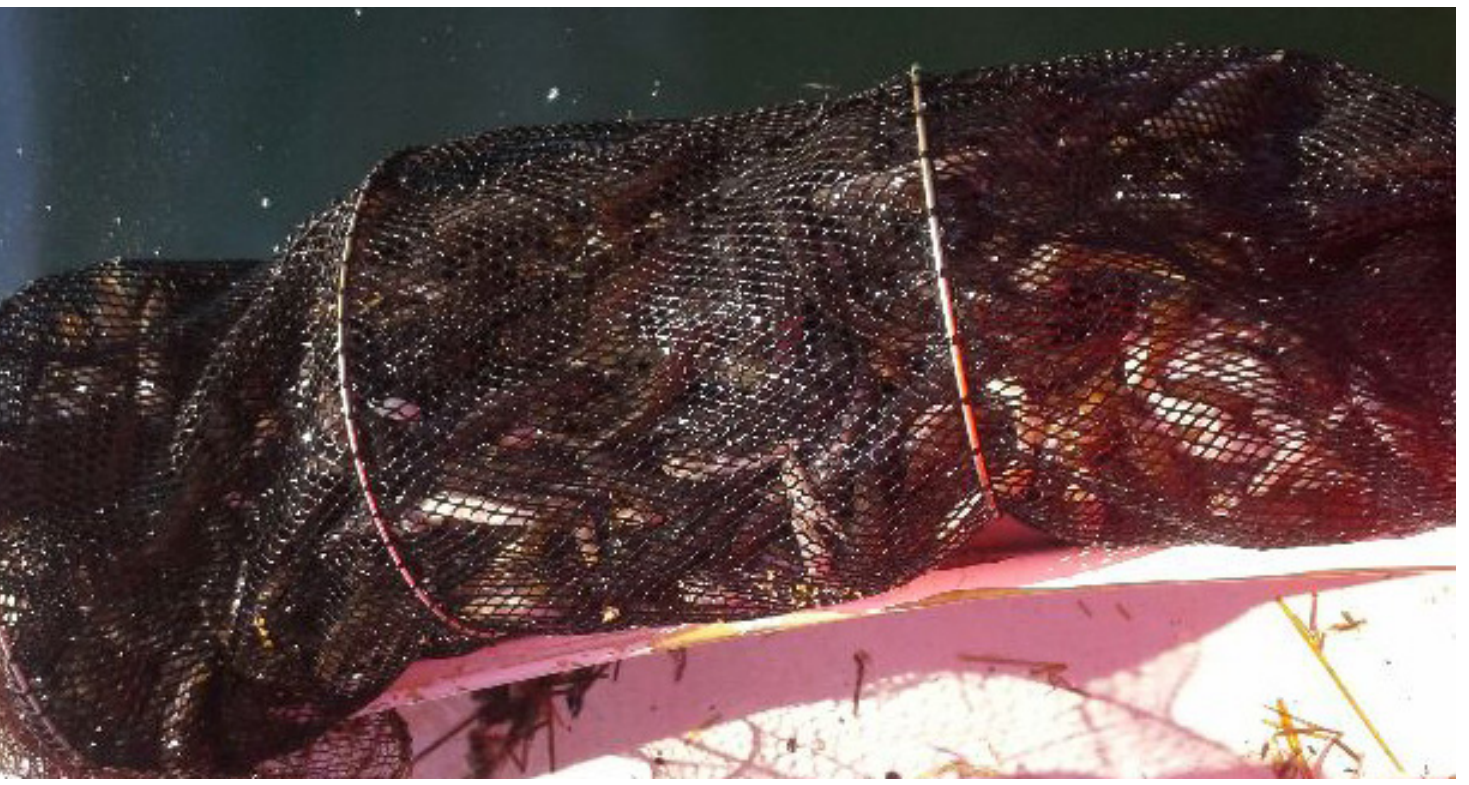

Round goby catch in passive gear. Kalvehave, Denmark. Photo: John Petersen

个

\section{The pan-Baltic invasion history of round goby and examples of negative impacts}

The round goby has been invading the Baltic Sea since early 1990 s and has established populations in all Baltic Sea sub-basins. It is currently considered one of the top invasive species in the Baltic Sea. Currently the species is expanding its range towards more saline waters in the west as well as to less saline waters in the north and east. Round goby has also entered fully freshwater environments, such as small rivers in Sweden and Denmark (Gotland 2016 and nearby Kalmar 2017), rivers in the northern coast of Estonia and is numerous in freshwater Curonian lagoon in Lithuania.

The round goby originates from the Ponto-Caspian region and was likely transported to the Baltic Sea via ballast water. The first record of the round goby in the Baltic Sea was made in Poland at the tip of Hel Peninsula, Gulf of Gdansk in 
1990 and by mid-1990's it was present in almost the entire Polish part of the Gulf of Gdansk, and had also been reported outside the Gulf. Round goby spread in the Baltic Sea occurred rapidly and by 2011, it was detected in all sub-basins. The spread in the Baltic Sea has followed a dual pattern: long-distance spread is associated with shipping and short distance natural spread locally.

The round goby has typical biological and ecological features for an invasive species such as rapid reproduction, aggressive behavior and ability to sustain variable biotic and abiotic conditions. Although their physiological performance in suboptimal environments (such as high salinity in western Baltic Sea) may be reduced to some extent, the increasing salinity towards the North Sea will likely not prevent further spread.

Round gobies are aggressive, territorial and voracious benthivorous fish. They exert top down impacts on their prey and competitive impacts on native species with similar ecology especially where numerous. Round gobies are generalists and opportunistic benthic predators reported to prefer bivalve prey, but their diets can be highly diverse and include a variety of benthic prey and even fish. Large round goby populations in the Lithuanian coast have likely contributed to local depletion of blue mussel banks. However, the fish appear to be able to persist and reproduce also where their preferred bivalve prey is not available or scarce (for example in the Bothnian Bay), indicating that the prey field is not limiting their success.

Species with similar ecology, such as the native black goby (Gobius niger), have decreased or vanished in many locations at the presence of round gobies. Furthermore, European flounder (Platichthys flesus) has shown a shift in its foraging as a result of increased round goby densities in many locations in the Baltic. In addition, the round goby is capable of consuming small flounders. 


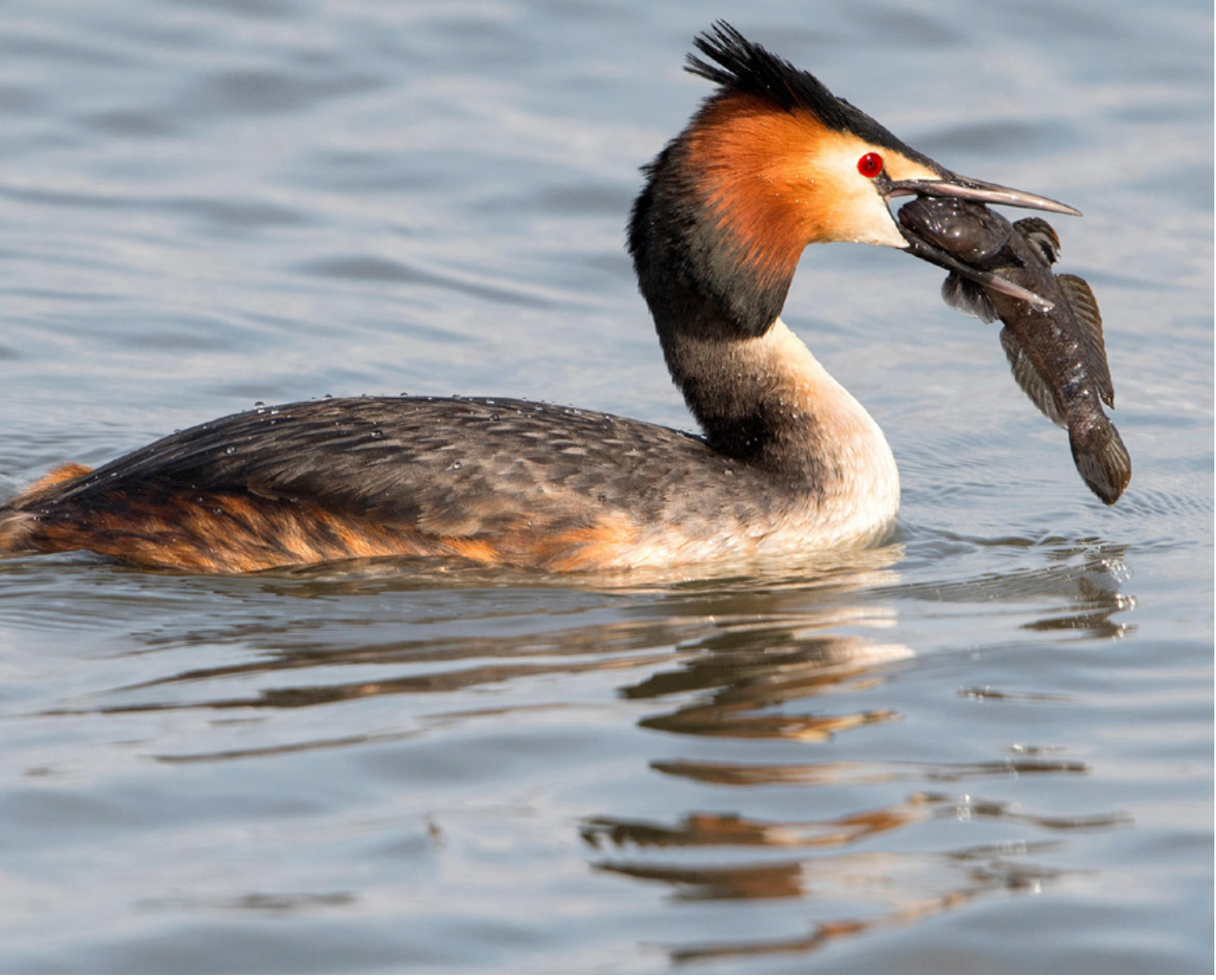

Great Crested Grebe with a round goby in its beak. Photo: Alamy $\uparrow$ 


\section{Round goby in relation to Good Environmental Status and Marine Protected Areas}

In the Marine Strategy Framework Directive (MSFD, 2008/56/EG) introduced species is included as a descriptor (Descriptor 2) of environmental status. In order to achieve Good Environmental Status (GES) introduced species must be on a level that does not affect the ecosystem negatively. The current high density of round goby in many areas of the Baltic Sea makes the likelihood large of negative effect on native fauna by for example predation and/or competition (see above) preventing the achievement of GES.

The invasion of round goby also affects the possibility to reach GES in other descriptors; maintaining biological diversity (Descriptor 1), populations of commercially exploited fish and shellfish species within safe biological limits, exhibiting a population age and size distribution that is indicative of a healthy stock (Descriptor 3), functional food web (Descriptor 4), sea floor integrity at a level ensuring benthic ecosystems not adversely effected (Descriptor 6). The invasion of round goby affects the possibility of member states to reach all these goals. However, round goby can also contribute to GES positively if marine exploited fish species like cod benefits from its abundance. Therefore, it is hard to foresee if the overall effect on the ecosystem of round goby will be positive or negative in the sense of good environmental status.

Marine protected areas (MPAs) are constructed to protect valuable and threatened species or habitat. However, many MPAs in Europe are situated in coastal shallow areas, i.e. suitable habitats for round goby and high abundance of round goby may compromise the objectives of the MPA. Since fishing is often prohibited in MPAs they could also become dispersal centers with a negative effect also in adjacent areas. It is therefore important when designing the MPA to also take the existence of nonindigenous species such as the round goby into consideration, and for example allow a selected removal of the species within the MPA or make sure the native predators are at a high abundance to mitigate negative effects from the round goby. 


\section{Round goby as an emerging prey item and potential new resource}

In regions where round gobies have become abundant, they have become important prey items for piscivorous predators. They are e.g. the main prey for cod and perch in the Gulf of Gdansk and increasingly important prey for perch in Estonia. In Lithuania round gobies were found in the diet of most piscivorous fish species including turbot or even such species as Shorthorn sculpin, the same being the case in the Curonian Lagoon, where it is part of the diet of all top predators. Some piscivorous fish, such as sander, show higher length-at-age values after the invasion. Furthermore, the nutritional value of round goby, having a high protein content and a favorable fatty acid composition makes it a superior prey for growth of cod. Round gobies are also important prey for piscivorous birds, such as great cormorant and grey heron. Thus, it is clear that positive effects of round goby are also to be seen in the wake of its invasion.
Round goby is target species for fisheries in its native range. It is considered tasty and it may gain popularity as a catch, also in the invasive range, and in Denmark and Sweden there are ongoing efforts to develop products for human consumption of the fish, e.g. fish filets and patties. The meat is fine, white, with a favorable texture, and fishing with passive gear is most cost-efficient in spring and early summer, where the fish are most active before breeding starts. In Latvia, a commercial fishery has developed and in 2018, more than 1000 tons were landed. Recreational angling for round goby has already become popular in Lithuanian coastal waters and the fish has become a valued catch. 


\section{Conclusions and recommendations}

Experience from all invaded regions show that when round goby has established, populations eradication is highly unlikely. Yet mitigation measures may ensure that densities are kept at acceptable levels to minimize negative impact on the invaded ecosystem. Fishing effort is an obvious mean to reduce abundances, yet it many countries round goby is not, at least yet, a valued species for human consumption. Often the public envisage the term 'invasive species' negatively, which does not foster utilization for human consumption, hence making it difficult for the fishers to obtain an acceptable prize. For example, in
Denmark the tabloid press has given the fish the nickname 'the killer slug of the sea'. Thus, branding is required, to create a positive image of the species.

After a few years where native predators have been reluctant to prey on this new fish, it is now clear that round goby constitutes a major proportion of the diet of predators foraging in coastal waters, especially piscivorous fish. Consequently, another way to keep control of the abundance of round goby is to support natural resilience by assuring that the predators of this fish are present in adequate amounts. 


\section{Contacts}

\section{Jane W. Behrens, Project lead}

National Institute of Aquatic Resources,

Technical University of Denmark

(DTU Aqua)

+4523296863

jabeh@aqua.dtu.dk

\section{Mikael van Deurs}

National Institute of Aquatic Resources, Technical University of Denmark (DTU Aqua)

+ 4521299390

mvd@aqua.dtu.dk

\section{Riikka Puntila-Dodd}

Marine Research Centre,

Finnish environment institute (Syke)

+358 295251545

riikka.puntila-dodd@environment.fi

\section{Ann-Britt Florin}

Department of Aquatic Resources

Swedish University of Agricultural

Sciences (SLU Aqua)

+46104784122

ann-britt.florin@slu.se

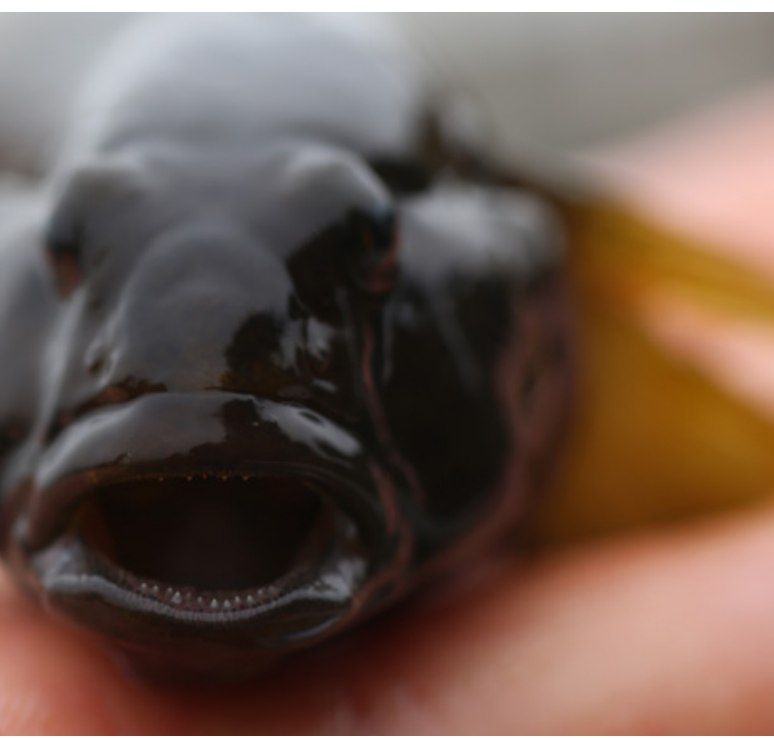

Round Goby

Photo: Mads

Christoffersen

$\leftarrow$ 


\section{Facts about round goby}

Latin name: Neogobius melanosomus.

Family: Gobiidae.

Habitat: Lives in coastal areas on shallow water, but migrate into deeper waters during the coldest months.

Reproduction: Spawning takes place from around May and until August, and a female may spawn up to six times during a season. Either eggs are laid onto various structures, or the males make nests in which several females spawn, and the males exhibit nest guarding behavior.

Area of origin and dispersal: Round goby is native to the Ponto-Caspian region and has been introduced to the Baltic Sea via ballast water in ships. From points of introduction (typically harbors) the fish has spread by migration along the coastline.

Food: Round goby has a broad diet, feeding on various invertebrate species, and on fish eggs, if available.

Round Goby.

Photo: Mads

Christoffersen

$\rightarrow$






\section{Selected literature}

Almqvist, G., A. K. Strandmark, and M. Appelberg. 2010. Has the invasive round goby caused new links in Baltic food webs?

Environmental Biology of Fishes 89:79-93.

Azour F., van Deurs M., Behrens J., Carl H., Hüssy K., Greisen K., Ebert R., Rask P.M. 2015. Growth and condition of the non-indigenous Round goby (Neogobius melanostomus) as a function of its invasion history. Aquat. Biol. 24, 41-52.

Balshine, S., A. Verma, V. Chant, and T. Theysmeyer. 2005. Competitive interactions between round gobies and logperch. Journal of Great Lakes Research 31:68-77.

Behrens J. W, van Deurs M. 2017. Evaluating dispersal potential of an invasive fish by the use of aerobic scope and osmoregulation capacity. PLoS ONE 12, e0176038.

Bzoma, S., 1998. The contribution of round goby (Neogobius melanostomus Pallas, 1811) to the food supply of cormorants (Phalacrocorax carbo Linnaeus, 1758) feeding in the Puck Bay. Bulletin Sea Fish Institute 2 (144): 39-47.

Charlebois, P. M., J. E. Marsden, R. G. Goettel, R. K. Wolfe, D. J. Jude, and S. Rudnika. 1997.
The Round Goby Neogobius melanostomus (Pallas) A Review of European and North. American Literature. Illinois-Indiana Sea Grant Program and Illinois Natural History Survey. INHS Special Publication No. 20.

Christoffersen M, Svendsen JC, Behrens JW, Jepsen N, van Deurs M. Using acoustic telemetry and snorkel surveys to study diel activity and seasonal migration of round goby (Neogobius melanostomus) in an estuary of the Western Baltic Sea. Fish Manag Ecol. 2019;26: 172-182.

Dietrich, J. P., B. J. Morrison, and J. A. Hoyle. 2006. Alternative Ecological Pathways in the Eastern Lake Ontario Food Web - Round Goby in the Diet of Lake Trout. Journal of Great Lakes Research 32:395-400.

Florin, A. B., Reid, D., Sundblad, G., \& Näslund, J. 2018. Local conditions affecting current and potential distribution of the invasive round goby-Species distribution modelling with spatial constraints. Estuarine, Coastal and Shelf Science, 207, 359-367.

Fenberg PB, Caselle JE, Claudet J, Clemence M, Gaines SD, García-Charton JA, Gonçalves EJ, Groud-Colvert K, Guidetti P, Jenkins SR, Jones PJS, Lester SE, Mcallen R, Moland E, 
Planes S, Sørensen TK (2012) The science of European marine reserves: status, efficacy, and future needs. Marine Policy 36: 10121021.

Hempel, M., Neukamm, R. and Thiel, R. 2016. Effects of introduced round goby (Neogobius melanostomus) on diet composition and growth of zander (Sander lucioperca), a main predator in European brackish waters. Aquatic Invasions, 11:167-178.

Jażdżewski, K., and A. Konopacka. 2002. Invasive Ponto-Caspian species in waters of the Vistula and Oder basins and of the southern Baltic Sea. Pages 384-398in E. Leppäkoski, S. Gollasch, and S. Olenin, editors. Invasive Aquatic Species of Europe. Kluwer Acad. Publ., Dordrecht, Boston, London.

Jakubas, D. 2004. The Response of the Grey Heron to a Rapid Increase of the Round Goby. Waterbirds 27:304-307.

Järv, L., J. Kotta, I. Kotta, and T. Raid. 2011. Linking the structure of benthic invertebrate communities and the diet of native and invasive fish species in a brackish water ecosystem. Ann. Zool. Fennici 48:129-141.
Karlson, A., Almqvist, G., Skora, K.E., Appelberg, M. 2007. Indications of competition between non-indigenous round goby and native flounder in the Baltic Sea. ICES Journal of Marine Science 64: 479-486. doi.org/10.1093/icesjms/fsI049.

Kornis, M. S., N. Mercado-Silva, and M. J. Vander Zanden. 2012. Twenty years of invasion: a review of round goby Neogobius melanostomus biology, spread and ecological implications. Journal of fish biology 80:235-85.

Kotta, J., K. Nurkse, R. Puntila, and H. Ojaveer. 2015. Shipping and natural environmental conditions determine the distribution of the invasive non-indigenous round goby Neogobius melanostomus in a regional sea. Estuarine, Coastal and Shelf Science 169:15-24.

Kuczyński J. 1995. Babka krągła N.melanostomus (Pallas 1811) - emigrant z Basenu Pon-tokaspijskiego w Zatoce Gdańskiej. Bulletin Sea Fish Institut, 2(135), 68-71.

Liversage K., Nurkse K., Kotta J., Järv L. 2017. Environmental heterogeneity associated with European perch (Perca fluviatilis) predation on invasive round goby 
(Neogobius melanostomus).

Mar Environ Res. 132:132-139.

doi: 10.1016/j.marenvres.2017.10.017.

Oesterwind, D., C. Bock, A. Förster, M. Gabel, C. Henseler, P. Kotterba, M. Menge, D. Myts, and H. M. Winkler. 2017. Predator and prey: the role of the round goby Neogobius melanostomus in the western Baltic. Marine Biology Research 13:188-197.

Ojaveer, H., Galil B., Lehtiniemi M., Christoffersen M., Clink S., Florin A.-B., S., Gruszka P., Puntila R., Behrens J. W. 2015. Twenty five years of invasion: management of the round goby Neogobius melanostomus in the Baltic Sea. Man. Biol. Invasions 6: 329-339.

Official Journal of the European Union, L 125/43, 18.05.2017.

Puntila, R., Florin, A.-B., Naddafi, R., Lehtiniemi, M., Behrens, J.W., Kotta, J., Oesterwind, D., Putnis, I., Smolinski, S., Wozniczka, A., Ojaveer, H., Ložys, L., Uspenskiy, A., Yurtseva, A., 2018. Abundance and distribution of Round goby (Neogobius melanostomus). HELCOM Baltic Sea Environment Fact Sheets. Online. 25.6.2019, http:// www.helcom.fi/baltic-sea-trends/environment-fact-sheets/biodiversity/abundance-and-distribution-of-round-goby/

Sapota, M. 2006. NOBANIS - Invasive Alien Species Fact Sheet Neogobius melanostomus.
Skabeikis, A. and Lesutiene, J. 2015.

Feeding activity and diet composition of round goby (Neogobius melanostomus, Pallas 1814) in the coastal waters of SE Baltic Sea. Oceanological and Hydrobiological Studies 44:508-519.

Skóra, K. E., and J. Stolarski. 1993. Neogobius melanostomus (Pallas 1811) a new immigrant species in Baltic Sea. Pages 18-22 Proceedings of the Second International Estuary Symposium held in Gdańsk.

Verliin, A., Kesler, M., Svirgsden, R., Taal, I., Saks, L., Rohtla, M., Hubel, K., Eschbaum, R., Vetemaa, M., Saat, T. 2017. Invasion of round goby to the temperate salmonid streams in the Baltic Sea. Ichthyol Res 64: 155-158.

Wallin, I. (2019). Affecting the ecosystem and being affected by it: the case of the non-indigenous round goby, N. melanostomus, in the Baltic Sea. Aqua Introductory Research Essay 2019:1. Swedish University of Agricultural Sciences, Department of Aquatic Resources, Drottningholm Lysekil Öregrund. pp 62.

Ustups, D., U. Bergström, A. B. Florin, E. Kruze, D. Zilniece, D. Elferts, E. Knospina, and D. Uzars. 2016. Diet overlap between juvenile flatfish and the invasive round goby in the central Baltic Sea. Journal of Sea Research 107:121-129. 
This Policy Brief was made under the project 'Value of the invasive round goby (Neogobius melanosomus) as prey for cod (Gadus morhua)', a project under the Marine Group (HAV) in the period 2018-2019, and financed by the Nordic Council of Ministers. Combining field samplings, lab work and modelling, the overarching aim of the project was to elucidate the potential of round goby as an emerging prey for cod, and how it may affect the growth potential of this piscivor predator. 


\section{Nordic Council of Ministers}

\section{Nordens Hus}

Ved Stranden 18

DK-1061 Copenhagen

www.norden.org

Originating from the Ponto-Caspian region, the invasive round goby has since 1990 spread in the Baltic Sea region, now with established populations throughout the area. The fish is a strong competitor for food, shelter and nesting sites, and has a high tolerance towards a broad range of temperatures and salinities. In many places, it exerts negative effects on the local fish fauna and benthic community, and its presence may compromise descriptors of Good Environmental Status under the Marine Strategy Framework Directive. Furthermore, Marine protected areas, constructed to protect valuable and threatened species or habitats, may be compromised by its presence. Notably however, round goby is also an emerging prey for larger fish, marine mammals and birds, thus providing positive effects to the invaded ecosystems. In some areas, it also supports fisheries, adding positively to society. 